\title{
Bank Swallows Nesting in Gravel Stock-Pile
}

\author{
by R. W. Nero, S.M.N.H.
}

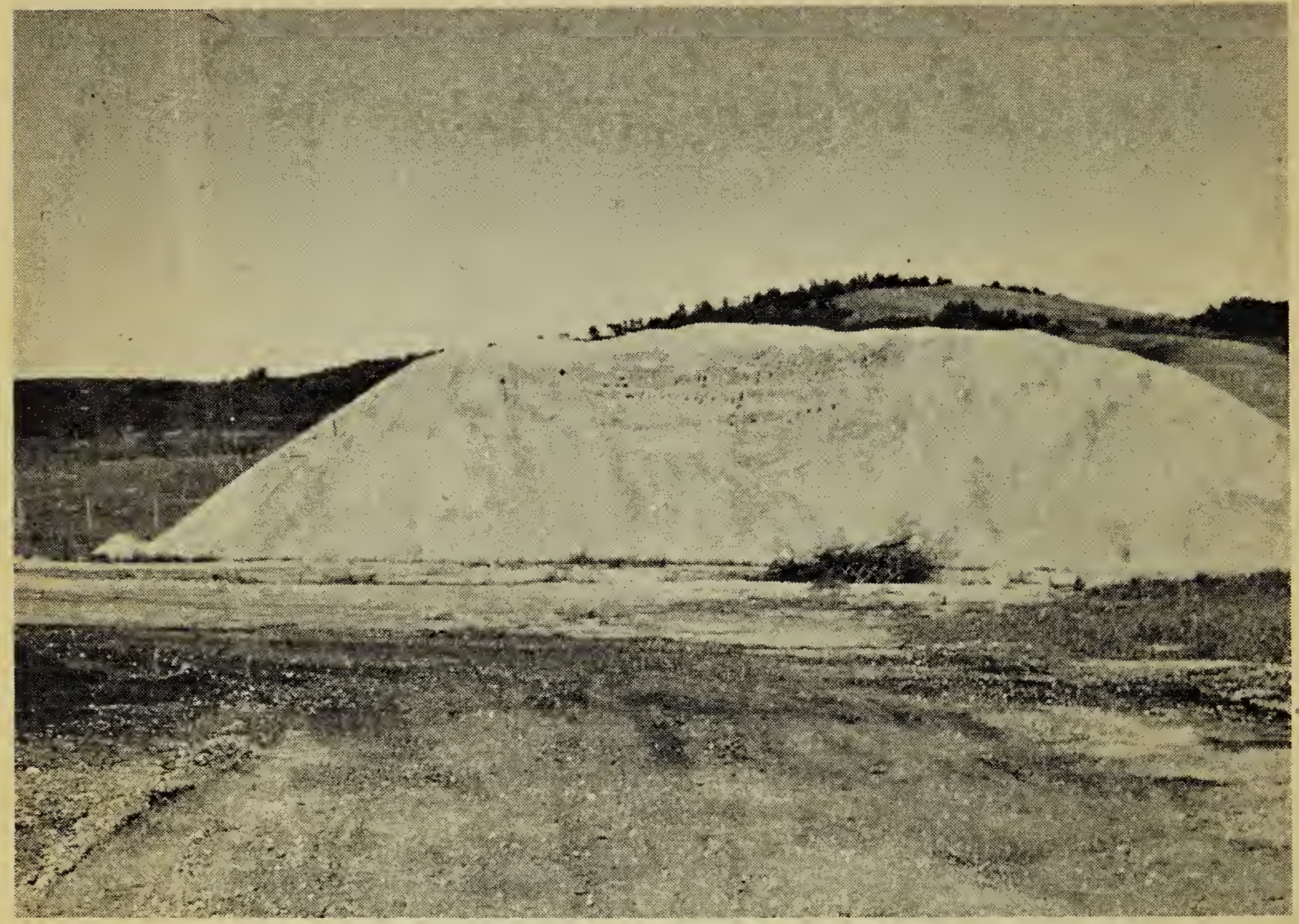

SMNH Photo

While en route to the Summer Meeting of the S.N.H.S. on June 12, 1959 , a group from the Museum including Bruce Shier, Janice Briggs, Joyce Dew and myself found a colony of Bank Swallows (Riparia riparia) nesting in a gravel stock-pile near the south entrance to Moose Mountain Provincial Park (in southeastern Saskatchewan). Although we did not take time to check nest contents, swallows were flushed from nearly every burrow and a general impression was obtained of a wellestablished colony. The Bank Swallow's habit of building burrows in sand banks of both natural and artificial origin is well known and it is even pointed out that a majority of colonies are located in artificial banks, e.g., railroad or road-cuts and sand and gravel pits (Stoner, 1936; Bent, 1942; Peterson, 1955). However, I was unable to find any reference to Bank Swallows building nest burrows in an artificial deposit of sand or gravel, even though stock-piles of such material are rather numerous.
Presumably the material in most stock-piles is too loose and lacks the compactness required for a more or less vertical wall to develop. The gravel stock-pile at Moose Mountain consisted of "pit-run" gravel, that is, a natural, unwashed mixture of small rounded pebbles, coarse sand and clay. Apparently the natural cementing action of clay in the mixture provided sufficient compactness, and further solidification of the mass was probably due to the packing action of bull-dozers building the stockpile, an action 'resulting in the horizontal layers which are apparent in the photo. Recently, after my mentioning this observation, Miss Margaret Belcher recalled a similar situation, and she kindly provided the following information from her notes. On July 24, 1955, while travelling in a train, she noticed that a small colony of Bank Swallows was established in a vertical face of a gravel stock-pile just south of Hanley, Saskatchewan. One other type of artificial deposit has served as a nest- 
site for Bank Swallows. W. B. Barrows and B. Torrey (in Bent, 1942: 404) report swallows nesting in sawdust piles lefit by lumbering operations. Bent has said sawdust piles are likely to prove to be precarious nesting sites; the same can be said for gravel and sand stock-piles which, of course, are generally in regular use.

\section{LITERATURE CITED}

BENT, A. C.

1942. Life histories of North American flycatchers. larks, swallows, and their allies. U.S. Nat'l Mus. Bull. 179, Smith-Inst., Wash., D.C.

PETERSON, A. J.

1955. The breeding cycle in the Bank Swallow. Wilson Bull. 67: 235-286.

STONER, D.

1936: Studies on the bank swallow Riparia riparia riparia (Linnaeus) in the Oneida Lake region. RooseveIt WiId Life Ann., vol. 9: 122-233.

\section{MOCKINGBIRD AT GRENFELL}

Mrs. John Hubbard of Grenfell reports seeing her first Mockingbird on November 7, 1960, in Grenfell. Although she did not expect a bird characteristic of the Deep South in Saskatchewan in November, Mrs. Hubibard was able to identify it to her satisfaction even without binoculars because she had a close view of the bird as it flew across the street in front of her and hopped from bush to bush in nearby shrubbery. The late date compares with other November dates on record: a male was taken at Skull Creek by S. A. Mann on November 1, 1929 (SMNH specimen); J. H. Taylor saw one in Regina on November 4, 1934; Lillian Hedley had one visiting her yard in Saskatioon through November, 1958, until it was killed by a cat December 9, 1958 .

\section{RIGHT ON COURSE!}

Interesting recovery of a banded Purple Finch

A beautiful male Purple Finch was found dead on April 30, 1960, by Peter Scott, at 182 Tupper Avenue, Yorkton. An observant lad, Peter noticed that the bird carried a small band. On reporting this, he learned that I had placed the band on this bird on May 17, 1959just half a mile easit of where he found it one year later. Although banding has proved that adult birds usually return to the same nesting site year after year, it is unusual to have evidence of a bird following exactly the same path during migration on two successive years. Purple Finches winter as far south as Texas, and are seen in Yorkton only on their way to the coniferous areas further north.-C. Stuart Houston, Saskatoon.

\title{
Third Annual Report of the Prairie Nest Records Scheme
}

\author{
by E. L. Fox, Regina
}

The Prairie Nest Records Scheme has just completed a third successful year. Since the scheme began, over 4,000 nest record cards have been turned in on 168 species of birds found breeding in the Prairie Provinces and the Northwest Territories.

In most cases, the cards have been submitted by amateur naturalists. This is an example of how the amateur can assist the professional in his research. Information on the breeding period, incubation period, and distribution of birds is urgently requimed. The amateur can assisit by accurately recording his observations on a nest record card, and submitting it to the Saskatchewan Museum of
Natural History for filing. It should be clear that information is required on even the most common bird breeding in your area, and that as much information as possible should be recorded on each nest found. Every interested person has access to the information contained in the Scheme's files.

By January 15, 1961, 37 contributors had submitted 1361 cards on nests found during 1960. Information was recorded on 145 species of birds. Some cards were received too late to be included in this reporit. Contributors should turn their cards in by Octobier 1, 1961. 